\title{
Erratum to: Establishing clones of Veratrum californicum, a native medicinal species, for micropropagation
}

Ju Yeon Song • Jacqueline Naylor-Adelberg •

Sarah A. White • David A. Mann • Jeffrey Adelberg

Published online: 4 July 2014

(C) The Society for In Vitro Biology 2014

Erratum to: In Vitro Cell. Dev. Biol. -Plant

DOI 10.1007/s11627-014-9603-7

In reference 11 , the journal name is incorrectly referred to as Hortic Sci. It should be HortScience.

The online version of the original article can be found at http://dx.doi.org/ 10.1007/s11627-014-9603-7.

J. Y. Song · J. Naylor-Adelberg $\cdot$ S. A. White $\cdot$ J. Adelberg $(\bowtie)$

School of Agricultural, Forest, and Environmental Sciences,

Clemson University, Clemson, SC 29634, USA

e-mail: jadlbrg@clemson.edu

\section{A. Mann}

Infinity Pharmaceuticals, Inc., Cambridge, MA 02139, USA 